\title{
JOSEPH CONRAD AND E. M. FORSTER IN SEARCH OF A TRANSCULTURAL SPACE
}

\author{
Narugopal Mukherjee \\ Bankura Christian College, West Bengal, India
}

\begin{abstract}
Only connect," this is the philosophy E. M. Forster popularizes in Howard's End and it becomes the central idea in his subsequent writings. Both Joseph Conrad and E. M. Forster speak of crossing the boundaries of culture and reaching out to the 'Other,' thereby turning their fictions into grand narratives of transculturalism. Conrad, in his novella, Heart of Darkness, and E. M. Forster, in his novel A Passage to India, feel an urgency to bridge up the gap between European imperialists and the natives, between the colonizer and the colonized, the exploiter and the exploited, whites and blacks, between 'us' and 'them,' thus advocating obliteration of all binary oppositions. Achebe might have criticized Conrad for his 'racist' bias but throughout his novel the focus is on tansculturalism, going across boundaries. Kurtz failed because he could not 'connect' properly. Forster speaks of the same in A Passage to India on a larger scale but in a more explicit manner. There are several attempts to 'connect' at personal, social, cultural, political, and even spiritual levels in the book. In the course of the novel Forster is in search of a 'lasting home' ("The Hill of Devi") under an open sky where people can come together on equal terms putting aside their racial and religious identities. Both Conrad and Forster are, thus, to be examined not just from a post-colonial perspective but from a broader philosophical one, where all lines of demarcation become dissolved and human entity is upheld. In this respect, both writers cross temporal and spatial boundaries and become universal.
\end{abstract}

Keywords: Heart of Darkness, A Passage to India, expansion, connection, transculturalism, grand narratives

Only connect! That was the whole of her sermon. Only connect the prose and the passion, and both will be exalted, and human love will be seen at its height. Live in fragments no longer. Only connect, and the beast and the monk, robbed of the isolation that is life to either, will die.

(Forster, Howards End 187; ch. 22)

E. M. Forster, an early $20^{\text {th }}$ century English novelist, employs the phrase "[o]nly connect" while referring to the relationship between Margaret and Henry, two major characters of Howards End, but the philosophy inherent in the lines quoted as a motto 
to the present article is applicable to literatures and cultures across the world. In another context Forster makes a fervent appeal to humanity at large: "connect without bitterness until all men are brothers" (Forster, Howards End 266; ch. 33). Forster, like the American poet Robert Frost in "The Mending Wall," speaks of an urgency to transcend all borders and barriers and embrace diverse, multiple, discordant, and divisive forces. And it is here that E. M. Forster and Joseph Conrad share common concerns and ideologies. The present paper seeks to explore those common ideas as reflected in Conrad's novella Heart of Darkness and Forster's A Passage to India, with a view to demonstrating how the two writers turn their fictions into grand narratives of transculturalism.

"Transculturalism," as Dirk Hoerder observes, "denote[s] the competence to live in two or more differing cultures and, in the process, create a transcultural space". It is "the process of individuals and societies to change themselves by integration of diverse cultural lifeways into a dynamic view-transitory-one" (Hoerder, 2010: 197). This sort of integration, or at least an attempt at one, is what can be detected in the two texts by Conrad and Forster.

Both the authors wrote in colonial times and about colonies. Both felt an urgency to bridge up the gap between European imperialists and the natives, between the colonizer and the colonized, the exploiter and the exploited, whites and blacks, between 'us' and 'them,' and thus advocated obliteration of all binary oppositions, disappearance of all shadow lines separating one from the other.

Both Heart of Darkness and A Passage to India bring to light issues of colonialism and imperialism against the backdrop of the British Empire. They both deal with cultural clashes, ideological assumptions, and the failure of the imperial mission in Africa and in India, respectively. Heart of Darkness definitely creates provisions for a discourse on colonialism and imperialism. Henryk Zins observes, Heart of Darkness is "exceptional in its condemnation of colonialism and in its humane attitude towards the African victims of imperialism" (Zins, 1982: 145). Apparently, the novella is, as many believe, an indictment against colonialism. Almost all the white men presented in the text treat colonialism as a glorious enterprise and a white man's responsibility to civilize barbarians. The unnamed narrator, as well as Marlow's aunt, appears to believe in King Leopold II of Belgium's declaration of 1898:

The mission which the agents of the State have to accomplish on the Congo is a noble one. They have to continue the development of civilization in the centre of Equatorial Africa, receiving their inspiration directly from Berlin and Brussels. Placed face to face with primitive barbarism, grappling with sanguinary customs that date back thousands of years, they are obliged to reduce these gradually. (qtd. in Kimbrough, 1988: 80)

In the same year, to support the royal stand, H. M. Stanley declared:

King Leopold II found the Congo [...] cursed by cannibalism, savagery, and despair; and he has been trying with a patience, which I can never sufficiently admire, to relieve it of its horrors, rescue it from its oppressors, and save it from perdition. (qtd. in Kimbrough, 1988: 80) 
Disease, death, and devastation that Marlow witnesses on his journey up the Congo River show the pointless brutality and bestiality of colonialism. Ironically enough, the white colonizers, forgetful of their civilizing "mission," themselves turn into beasts.

The usurpation of land and violation of human rights, rampant throughout the Belgian colony, hint at the hollowness of imperialism. It is darkness rather than light that the colonizers bring along, turning the occupied lands into infernos. Marlow notices how the natives are dehumanized as they are referred to as "shapes," "bundles," and "phantoms". They remain the 'Other' in this colonial enterprise, but the lust for ivory so pronounced in Kurtz and his rivals points to the corrupting influence of colonialism also on the colonizers themselves. The members of the Eldorado Exploring Expedition are dedicated solely to the task of collecting ivory: "To tear treasure out of the bowels of the land was their desire, with no more moral purpose at the back of it than there is in burglars breaking into a safe" (Heart of Darkness, ed. Bose 52). Marlow exposes the chasm between imperial declarations and the brutal imperialistic practice. In fact, through Marlow's narrative, Conrad might be expressing his own attitude towards imperialism. Marlow and through him Conrad denounces imperialism as practised in the Congo.

Frances B. Singh, like most critics, acknowledges Heart of Darkness as one of the most powerful indictments of colonialism ever written" (Singh, 1988: 268). He argues that "[a]s a child Conrad was a victim of Russia's colonialistic policies toward Poland" (268), which might have been the reason why the writer was so much against colonialism, attempting to expose the exploitation that went "under the cover of brotherhood and philanthropy" (269). In his 22 July 1896 letter to T. Fisher Unwin, Conrad makes it clear that it was his "indignation at masquerading philanthropy" that led him to writing his novella (qtd. in Kimbrough, 1988: 199). He made it clear to his publisher, William Blackwood in 1898 that the idea that impelled him to write this novella was the "criminality of inefficiency and pure selfishness when tackling the civilizing work in Africa" (Blackburn, 1958: 36-37). The novella was definitely aimed at criticizing the colonialists in the continent. Hugh Clifford referred to it as a "study of the Congo," and Edward Garnett as "an impression taken from life, of the conquest by the European whites of a certain portion of Africa, an impression in particular of the civilizing methods of a certain great European Trading." Conrad as a writer of fiction could not ignore the history, the facts of life. He believed that "Fiction is history, human history, or it is nothing," that a "novelist is a historian, the preserver, the keeper, the expounder, of human experience" (Notes on Life and Letters 17). In Heart of Darkness Conrad narrates his experiences, the brutal inhuman acts that he witnessed in Africa. Jonah Raskin very significantly observes:

Conrad transformed a personal experience into a fiction of general historical and cultural significance. With little sense of strain, he moved from self to society; it was one of his eccentricities to mythologize an historical self, to place his own life at the heart of historical conflicts. He was the 'Polish Englishman,' Easterner and Westerner; he saw himself at the centre of rival European nationalisms ... Conrad placed himself at and was fascinated by frontiers-mythical frontiers between Poland and England, civilization and savagery, industrialism and pastoralism, 
and these social and historical tensions were made the tensions of his novels. (Raskin, 1967: 115-116)

Edward Said defended Conrad by saying that Conrad is a creature of his time and historicizes and contextualizes him as someone who could see the evils of imperialism but could not offer an alternative view (Said, 1994: 22-30).

Chinua Achebe, however, takes a different stance. While attacking Conrad on racial grounds and claiming that "Joseph Conrad was a thoroughgoing racist," he rejects Heart of Darkness as a great work of art (Achebe, 1977: 257). According to Achebe, Africa used as a setting and a backdrop "eliminates the African as human factor," for it is then represented as "a metaphysical battlefield devoid of all recognizable humanity, into which the wandering European enters at his peril" (257). Thus Achebe protests against underestimation of Africans:

Heart of Darkness projects the image of Africa as "the other world," the antithesis of Europe and therefore of civilization, a place where man's vaunted intelligence and refinement are finally mocked by triumphant bestiality [...] The real question is the dehumanization of Africa and Africans which this age-long attitude has fostered and continues to foster in the world. (Achebe, 1977: 252-257)

The Nigerian critic is not even ready to consider Conrad's text as a work of art. The question, he argues, "is whether a novel which celebrates this dehumanization, which depersonalizes a portion of the human race, can be called a great work of art. My answer is: No, it cannot" (257). Caryl Phillips, however, draws our attention to Achebe's awareness of Conrad's doubts over the real purpose behind colonization: "Achebe is, however, aware of Conrad's ambivalence towards the colonising mission, and he concedes that the novel is, in part, an attempt to examine what happens when Europeans come into contact with this particular form of economic and social exploitation" (Phillips, 2003).

Colonialism as presented in Heart of Darkness is not simply a political or historical phenomenon; it is also a discourse involving lust for power and wealth. It is a study of the evils deeply rooted in the human heart, the "heart of darkness." "T. S. Eliot read it as a work about evil, life's bleak hopelessness, and moral emptiness, neglecting the 'affirmation' and 'victory' and transforming the 'horror' which refers particularly to the Belgian Congo to a horror of life in general" (qtd. in Raskin, 1967: 114). Ian Watt thinks that Conrad's aim is not really to support or criticize colonial policies. He is "neither a Utopian writer nor an apocalyptic one" (93). Watt says: "Conrad's writing and his mind in general aim to advance, not political programs, but moral understanding; and this is true of "Heart of Darkness". Caryl Phillips quite pertinently observes:

The novel proposes no programme for dismantling European racism or imperialistic exploitation ... I have always believed that Conrad's only programme is doubt; in this case, doubt about the supremacy of European humanity, and the ability of this supposed humanity to maintain its imagined status beyond the high streets of Europe. (Phillips, 2003) 
Indeed, Conrad does not narrow down his novella simply to the discussion of the evils of imperialism or colonialism. He has something more significant to contribute. The journeys that Marlow undertakes to the 'heart' of 'darkness' take us on to the discovery of our real character, the 'darkness' within, the evil within us. Phillips significantly remarks:

Conrad uses colonisation, and the trading intercourse that flourished in its wake, to explore [the] universal questions about man's capacity for evil. ... Conrad was interested in the making of a modern world in which colonisation was simply one facet. The uprootedness of people, and their often disquieting encounter with the "other," is a constant theme in his work, and particularly so in this novel. Conrad's writing prepares us for a new world in which modern man has had to endure the psychic and physical pain of displacement, and all the concomitant confusion of watching imagined concrete standards become mutable. Modern descriptions of 20th-century famines, war and genocide all seem to be eerily prefigured by Conrad, and Heart of Darkness abounds with passages. (Phillips, 2003)

Heart of Darkness is, thus, not just a statement on racism or imperialism; it is a philosophical novel that has multiple layers of meaning. The urge for creating a transcultural space is one of those major issues.

Anyone who puts practical, political, or national issues first could not be expected to like Heart of Darkness. Its tendency to universalize the problems raised by the Congo and Kurtz, and yet express them in a sophisticated and subjective dramatic form through Marlow's consciousness, shows a temper of mind very different, and in some respects opposed to, Frantz Fanon's classic statement of the colonial problem. The only condition on which Fanon sees the possibility of the Europeans being able to help the Third World is that "they should join in a common effort to rehabilitate mankind, and make man victorious everywhere, once and for all" (92). The novella, thus, is more on expansion of humanity, on removal of darkness of heart, than on colonialism or imperialism. Raskin rightly says, "He [Conrad] believed that "the bitterest contradictions and the deadliest conflicts of the world are carried on in every individual capable of feeling and passion'. For him the conflicts he witnessed in the Belgian Congo illuminated the conflicts of the modern world; he had only to give them shape and significance, set down on paper, to chronicle a phase of history. In writing out of his self he was mythologizing the contemporary world" (Raskin, 1967: 116). Conrad thought of political strife, crises that the Africans faced and their basic instability as something more significantly connected with human nature and experience.

E. M. Forster's A Passage to India also deals with colonial issues and exposes the racial bias of every colonizer in India. While writing this particular novel, Forster had in mind the key political event of 1919, the Jalianwala Bagh Massacre, in which hundreds of Indians joining in a peaceful demonstration were brutally killed in retaliation for an attack on an English woman missionary. The racial hostility and recrimination that followed the alleged attack on Adela in the novel are what we come across in all kinds of fiction of the day which deals with colonial issues. Just as in Heart of Darkness, here too, the colonizers are shown as masquerading under the guise of brotherhood and philanthropy only to turn into monsters devoid of all morality and 
humanity the next day. While talking to Hamidullah and Mahmoud Ali, Dr. Aziz complains:

They come out intending to be gentlemen, and are told it will not do. Look at Lesley. Look at Blakiston, now it is your red-nosed boy, and Fielding will go next [...] They all become exactly the same-not worse, not better. I give any Englishman two years, be he Turton or Burton. It is only the difference of a letter. And I give any Englishwoman six months. All are exactly alike. (Forster, 2005: 9)

The same ironic realization comes to Marlow in Heart of Darkness: "I also was a part of the great cause of these high and just proceedings" (Conrad, 2001: 37). That he has likewise joined the devil's party becomes clear to Marlow in the course of his journey into the pre-historic jungle.

In Forster's novel Major Callendar, the Civil Surgeon, always puts Aziz in trouble only because the latter is a native, so he deems it his duty to interrupt Aziz "in order to show his power" (Forster, 2005: 13) every time the doctor is found having some entertainment with his friends. At the Bridge Party that the Collector arranges, the white men and women distance themselves from the Indians, considering it to be below their dignity to speak to the natives. Mrs. Turton even comments: "They ought never to have been allowed to drive in" (17). A little later she adds: "Why they [the Indians] come at all I don't know" (18). The colonizer's real face is revealed when Ronny makes it clear to Mrs. Moore, his mother, that they are not out here "for the purpose of behaving pleasantly!" He further explains: "I am out here to work, mind, to hold this wretched country by force. I'm not a missionary or a Labour Member or a vague sentimental sympathetic literary man. [...] We're not pleasant in India, and we don't intend to be pleasant" (45). McBryde, the District Superintendent of Police, who believes in the age-old theory that "[a]ll unfortunate natives are criminals at heart, for the simple reason that they live south of latitude 30" (156), seems to conveniently support Ronny's attitude.

Similarly, Hamidullah's question to Fielding: “[...] how is England justified in holding India?" (Forster, 2005: 102) appears to find an ironic answer in the trial scene of Dr. Aziz, which further exposes the Englishmen's disguise of humanity, morality, and justice as they try to dominate the entire court procedure. Their authority supposedly conferred by "chairs ordinary and special, strips of carpet, platforms one foot high" (209) gives the Anglo-Indians an edge over the Indians as they are so desperately trying to vindicate their colonial rule in India. It is Amritrao, the barrister from Calcutta, who objects to this hidden agendum of interfering with the judicial process: "We object to the presence of so many European ladies and gentlemen up on the platform [...] They will have the effect of intimidating our witnesses" (208). After his release Dr. Aziz decides to isolate himself from the British colonizers: "I have decided to have nothing more to do with British India" (237). He finds the colonial rule so offensive that he seeks its ouster from India: "India shall be a nation! No foreigners of any sort! [...] we shall get rid of you, yes, we shall drive every blasted Englishman into the sea" (306). Thus both Heart of Darkness and A Passage to India, at least apparently, deal with racial conflict. 
The way Forster begins A Passage to India seems to hint at a centuries old prejudice of the Europeans against their colonized lands. In the trial scene $\mathrm{Mr}$. McBryde makes a racist remark about Indians as well as blacks: "[...] the darker races are physically attracted by the fairer, but not vice versa" (Forster, 2005: 206). There are a number of negative suggestions regarding the bitter racial relationship between the British and the Indians in the opening chapter of Forster's novel: "the rubbish it [the Ganges] deposits"; "no bathing steps"; "no river front"; "bazaars shut out"; "[t]he streets are mean, the temples ineffective"; "[i]n the bazaars there is no painting and scarcely any carving"; "[t]he very wood seems made of mud, the inhabitants of mud moving"; "[s]o abased, so monotonous is everything that meets the eye"; "[h]ouses do fall, people are drowned and left rotting" (Forster, 2005: 5), etc. Peter Childs comments: "The Indian people are figured as "some low but indestructible form of life,' in which phrase Forster reveals his Western conditioning and prejudices" (Childs, 2004: 117).

A similarly negative description can be found in Marlow's depiction of the Central Station in Heart of Darkness: "Everything else in the station was in a muddleheads, things, buildings. Strings of dusty niggers with splay feet arrived and departed; a stream of manufactured goods, rubbishy cottons, beads, and brass-wire set into the depths of darkness [...]" (40). However, neither of the two writers, in reality, seeks to dehumanize the natives. Rather, they raise the issue of their inhuman treatment. Conrad's anti-colonial stand is more than obvious in Marlow's account:

It was just robbery with violence, aggravated murder on a great scale, and men going at it blind [...] The conquest of the earth, which mostly means the taking it away from those who have a different complexion or slightly flatter noses than ourselves, is not a pretty thing when you look into it too much. (Conrad, 2001: 27)

Conrad's description of the natives evokes our sympathy for the colonized and depicts the inhuman treatment that went under the masquerade of philanthropy:

Six black men advanced in a file, toiling up the path. [...] Black rags were wound round their loins, and the short ends behind waggled to and fro like tails. I could see every rib, the joints of their limbs were like knots in a rope; each had an iron collar on his neck, and all were connected together with a chain [...]. (37)

Another passage brings to light the oppression the Congolese were subjected to:

They were dying slowly - it was very clear. They were not enemies, they were not criminals, they were nothing earthly now - nothing but black shadows of disease and starvation, lying confusedly in the greenish gloom [...] lost in uncongenial surroundings, fed on unfamiliar food, they sickened, became inefficient, and were then allowed to crawl away and rest. (38)

Moreover, irony is sharp and pointed in expressions like: a "noble cause"; "the cause of progress"; "glorious affair" (30); "[s]omething like an emissary of light, something like a lower sort of apostle" (33); "I was also a part of the great cause of these high and just proceedings" (37). All these point to Conrad's anti-colonial standpoint. But Conrad does not assert anything about political aspects or colonial poli- 
cies. He is simply asking the readers to join Marlow in his search for truth, in his transformation from an enthusiastic and inquisitive youth to a meditating Buddhalike figure.

The same is true about Forster. He has all the sympathy for the Indians as expressed through Fielding or the Principal of the Government College, who singlehandedly protests against the dehumanization of Dr. Aziz. That the writer was all against this inhuman action is reflected in his conception of the plot. In fact, he does not clearly point out what exactly happened in the Marabar Caves. In a letter to G. L. Dickinson, Forster writes: "In the cave it is either a man, or the supernatural, or an illusion. And even if I know!" (qtd. in Furbank, 1998: 125). The writer deliberately evades a detailed account of what happened in the Caves as if to demonstrate how mere assumptions or speculations can lead to a disaster like the one people witnessed at Amritsar.

The two novels, however, also unravel more significant issues than those mentioned above. In both there have been attempts at crossing the boundaries even if those attempts eventually lead to disasters, at least in their immediate contexts. Forster made his goal very clear in his Prefatory Note (1957) to the Everyman Edition of A Passage to India: In writing [the novel], however, my main purpose was not political, was not even sociological" (2005: 307). In "Three Countries" again Forster stated unambiguously:

[...] the book is not really about politics, though it is the political aspect of it that caught the general public and made it sell. It's about something wider than politics, about the search of the human race for a more lasting home, about the universe as embodied in the Indian earth and the Indian sky. [...] It is, or rather desires to be-philosophic and poetic. (Forster, 1983: 298)

Forster's main concern in A Passage to India is to create a transcultural space, a lasting home for everyone and everything around. There are several attempts to 'connect' on the personal, social, cultural, political, and even the spiritual levels in the novel. Mrs. Moore, Adela, Dr. Aziz, Fielding, Godbole-almost all the major characters get involved in these attempts but fail in the end. Even on the personal level Aziz and Fielding cannot cross the boundaries because of their unequal relationship: one the 'ruler,' the other 'ruled.' In the book Forster is in quest for a 'lasting home' under an open sky, where people could come together on equal terms, putting aside their racial and religious identities. Cyril Connolly puts it quite pertinently:

[...] the novels of Forster state the general conflict which is localized in the political conflict of today. His themes are the breaking down of barriers: between white and black, between class and class, between man and woman, between art and life. "Only connect [...]," the motto of Howards End, might be the lesson of all his work. (Connolly, 1961: 18)

Hence Mrs. Moore takes off her shoes while entering the mosque. It "makes no difference" to her that "no one is there to see" because "God is here" (Forster, 2005: 17). She thus crosses the barrier between religions, recognizing God everywhere and connecting one religion with the other. This is the first attempt in the novel towards creating a transcultural space. A little later Dr. Aziz pays Mrs. Moore a compliment: 
"Then you are an Oriental!" (20). This very word 'Oriental' is the connecting point between the two races - the colonizers and the colonized - and the shadow lines become blurred. Mrs. Moore's earnest desire: "I want to see the real India" (21), becomes another important link between the two races. When going to bed after her conversation with Ronny she finds a small wasp occupying the tip of the peg, the wasp becomes a connecting point between the western and Indian philosophies. The elderly lady's affectionate - "Pretty dear" (31) — well illustrates her ardent wish to remove the barriers between East and West, between the human and the nonhuman.

It is all-inclusiveness that Forster advocates in his novels, and the note of intimacy in Mrs. Moore's voice erases the borders between divergences in whatever form they may appear. The sky with its many colours, tints, and shades of difference becomes a potent symbol in the novel, suggesting its all-inclusive aspect. At the very outset of the novel the writer makes it clear that " $[\mathrm{t}]$ he sky settles everything- not only climates and seasons, but when the earth shall be beautiful" (Forster, 2005: 6). E. M. Forster makes the point that political, cultural, social, or economic divergences, the 'muddles' (63), will always hinder all possible associations, and it is only the overarching sky that can connect one with the other, on both the physical and metaphysical levels, disseminating the universal values that Forster believed in.

In Heart of Darkness Conrad is more concerned with the need for a humane face in the colonial enterprise than Forster is in his novel. Through Kurtz's last words on his death-bed; "The horror! The horror!" (96), the author sends a message to the white colonizers that they must change their attitude to the natives; otherwise human existence will perish. Kurtz enjoys wide acceptance and popularity among the natives despite his obsession with ivory and the immorality associated with it, only because he can feel the native pulse, the very spirit of the primitive tribes, and becomes intimate with it. Marlow thus interprets the last few moments of Kurtz's life: "I understand better the meaning of his stare, that could not see the flame of the candle, but was wide enough to embrace the whole universe, piercing enough to penetrate all the hearts that beat in the darkness" (97). In spite of "the strange comingling of desire and hate" (97) in his nature, Kurtz is successful as a trader since he manages to expand his power and include everybody in his enterprise. Expansion and inclusion thus mark Kurtz's success as a colonial agent but become his undoing as a human being.

Expansion and inclusion are also what Forster emphasizes in A Passage to India. One of the key social, political, and religious themes of the novel is that of an invitation to create a 'passage,' a link, a connection between races. Upon the request of Mrs. Moore, so keen to see "the real India," the Collector sends an invitation to numerous Indians in the neighbourhood to a Bridge Party to be arranged at the Club. However, the Bridge Party fails to bridge up the gap. The Indians "stood massed at the further side of the tennis lawns, doing nothing" (Forster, 2005: 35). The invitation extended by the Anglo-Indian community is insincere and it lacks goodwill. The colonizers have no intention of getting connected with the Indians. Peter Childs observes: "The English are physically separate but also emotionally pre-disposed to segregate and differentiate" (Childs, 2004: 122). E. M. Forster comments: "All invi- 
tations must proceed from heaven perhaps; perhaps it is futile for men to initiate their own unity, they do but widen the gulfs between them by the attempt" (Forster, 2005: 34). The writer seems to suggest that the solution to all cultural misunderstanding does not lie with political institutions but human capacity to transcend the differences by developing the heart and imagination.

Aziz's invitation to Mrs. Moore and Adela to visit the Marabar caves is another attempt at crossing the borders, the demarcation lines between the colonizers and the colonized. However, it leads to a total disaster and worsens the racial relations in the community. Heaslop's manhood is challenged by a native's (and thus his subordinate's) attack on his fiancée, so he is determined to see the man hanged. Nevertheless, Aziz is finally declared innocent and is released. Thus, the prospect of crossing the boundaries is not lost forever, which is why Aziz and Fielding, representatives of both races, finally meet and consider renewing their friendship.

A journey from the mundane to the divine, with a bid to creating a passage between the two, is undertaken in both novels. In Heart of Darkness, Conrad describes the journey through an exotic landscape as a spiritual voyage of discovery presented by French symbolists Baudelaire and Rimbaud in "Le Voyage" and "Bateau ivre," respectively. In fact, Marlow's journey has two aspects to it, outward and inward, i.e., his encounter with the real nature of colonialism and his introspective journey of selfdiscovery, leading to an inner, spiritual change. Marlow's journey to the 'heart of darkness' and his discovery of the evils of imperialism, a discovery of "the discrepancy between its Romantic ideals and sordid material practice" (Eagleton, 1976: 134) remain the central preoccupations of the novella. It is indeed a self-discovery for Marlow as he tells his fellow seamen: "It was the farthest point of navigation and the culminating point of my experience" (Conrad, 2001: 28). It seems to "throw a kind of light on everything" (28) about him and on his thoughts. Though initially he is under the illusion of "[s]omething like an emissary of light, something like a lower sort of apostle" (33), engaged in the "noble cause" (30) of progress, of "weaning those ignorant millions from their horrid ways" (33), Marlow soon discovers the real nature of imperialism. Instead of "going to the centre of a continent," he feels he is about to set out "for the centre of the earth" (34), and indeed the real faces disguised under the masks are exposed to him. On his voyage along the edge of the colossal jungle, he stops at some places and witnesses how "the merry dance of death and trade goes on in a still and earthy atmosphere as of an overheated catacomb" (35). A general sense of "vague and oppressive wonder" descends upon him. He soon senses the binaries prevalent in the region: myth/reality, white/black, light/darkness. The plight of the six black men with rags and iron collars on their necks gives him a premonition of the sort of exploitation of the natives he is going to witness later. The outward journey turns into an inward one. He soon realizes the futility of the imperial mission as he sees a native digging a vast hole for no apparent reason: "It might have been connected with the philanthropic desire of giving the criminals something to do" (38).

Marlow's journey goes beyond the constraints of time and unravels the pre-political sources of 'civilization'. In the words of Marlow: "Going up that river was like travelling back to the earliest beginnings of the world, when vegetation rioted on the 
earth and the big trees were kings ... You lost your way on that river as you would in a desert ... till you thought yourself bewitched and cut off forever from everything you had known once - somewhere - far away — in another existence perhaps. There were moments when one's past came back to one ... but it came back in the shape of an unrestful and noisy dream, remembered among the overwhelming realities of this strange world of plants, and water, and silence. And this stillness did not in the least resemble a peace" (Youth 92-93).

Marlow makes his final self-discovery immediately after Kurtz's death: "Droll thing life is - that mysterious arrangement of merciless logic for a futile purpose. The most you can hope from it is some knowledge of yourself - that comes too latea crop of unextinguishable regrets" (96). This realization and self-discovery that come at the end of Marlow's voyage are sacred. They remain beyond the spheres of the mundane and the materialistic. They are therefore philosophical, spiritual.

In A Passage to India the journey is undertaken by Professor Godbole. He acts as a linking agent between humanity and spirituality. His "whole appearance suggested harmony - as if he had reconciled the products of East and West, mental as well as physical, and could never be discomposed" (Forster, 2005: 66). He sends a series of invitations to God: "I say to Him, Come, come, come, come, come, come. He neglects to come" (73). Presence and absence are necessary aspects of the divine. God's refusal to come results in an utter anarchy at the physical level. However, Godbole's interpretation of absence is quite positive: "[...] absence implies presence, absence is not nonexistence, and we are therefore entitled to repeat, 'Come, come, come, come'" (167). Forster thus implies a hope for all connections coming together at a certain point in time. This is what Aziz and Fielding experience in the final scene as they ride together side by side. Despite their goodwill and sincere wishes they cannot be friends because friendship is based on equality. The political and racial differences between them prevent their friendship.

And it is here that Forster's view of transculturalism is shown as deeply rooted in power and politics. More than a philosophy, it becomes a postcolonial discourse. However, E. M. Forster is far from a downright negation of friendship or interhuman connections; instead, he keeps the issue open-ended for the critics and readers to comment on:

'Why can't we be friends now?' said the other, holding him affectionately. 'It's what I want. It's what you want.'

But the horses didn't want - they swerved apart; the earth didn't want it, sending up rocks through which riders must pass single-file; the temples, the tank, the jail, the palace, the birds, the carrion, the Guest House, that came into view as they issued from the gap and saw Mau beneath: they didn't want it, they said in their hundred voices, 'No, not yet,' and the sky said, 'No, not there.' (Forster, 2005: 306)

Forster keeps all options open with the words "not yet," implying that in future it might be possible. Thus, a transcultural space could be created when the two races or two warring groups would negotiate with one another at the same level, forgetting all about their egoistic selves, being oblivious of all binaries like ruler/ruled, colonizer/ colonized, white/black, privileged/under-privileged. 
Kurtz, the colonizer-turn-ivory trader in Conrad's novella, makes an attempt at imbibing a kind of transcultural status. He is, in fact, a combination of many facets of life. His personality is an amalgamation of a variety of people who lived in the region at that time. He has a hybridized nationality and in that sense he has acquired through his very birth a transcultural identity: "His mother was half-English, his father was half-French. All Europe has contributed to the making of Kurtz" (Conrad, 2001: 74). $\mathrm{He}$ is a painter, musician, writer, orator, philanthropist, and the company's best agent, thus combining in himself the values of a high culture. But away from society, he liberates himself from all the restraints and becomes his own diabolical god. $\mathrm{He}$ alienates himself from the imperialists with a bid to get connected with the natives. The chief single deflection for Kurtz is definitely his frantic rapacity for ivory, which he turns into a brilliant material success. His social identity becomes thereby transformed obviously to keep the "ivory flowing and colonialism a profitable venture for his employers" (Singh, 1988: 277).

However, originally, it is only Kurtz who is able to become intimate with the natives so much so that the brick maker at the Central Station describes him as "a prodigy," "an emissary of pity and science and progress, and devil knows what else" (Conrad, 2001: 47), and the chief accountant calls him "remarkable" (40). Even the motley Russian adores him in unambiguous terms. In this sense Kurtz appears to be successful in transgressing the human boundaries in his community and creating a transcultural space for himself. Although Marlow believes that Kurtz is depraved and his tribalisation is to satisfy his lust for sex and wealth, Kurtz's followers find nothing abominable in his conduct. From their standpoint "Kurtz's tribalisation can be seen as rejection of the materialism of the West in favour of a simpler and more honest life" (Singh, 1988: 276). Certainly from postcolonial standpoint also Kurtz's tribalisation is a protest against imperialism. Kurtz's last words "The horror! The horror!," as Singh observes, refer to "what Kurtz has done to the blacks ... the full application of Kurtz's last words would not only be to himself but also to men like Marlow who seemed to hate colonialism but really lived by its values" (276). Both Kurtz and Marlow come to the realization of what imperialism has done in Africa.

Kurtz's Intended, who knows nothing about his real dealings in the Congo, has only words of praise for him. She tells Marlow:

“"It was impossible to know him and not to admire him. [...] I had all his noble confidence. I knew him best. [...] I am proud to know I understood him better than any one on earth [...] Who was not his friend who had heard him speak once? [...] He drew men towards him by what was best in them. [...] What a loss to me-to us! [...] To the world."' (Conrad, 2001: 101-103).

The European Intended is a parallel of Kurtz's African woman. This, ironically, illustrates Kurtz's achievement in crossing all barriers between races and colours and producing a transcultural identity for himself.

However, Kurtz fails to win the confidence of the European community. He also fails to turn into a native fully and can never inculcate the positive values of the local tribes. He never becomes one of them. Marlow realizes that Kurtz's ideals are all superficial. Kurtz fails because he cannot 'connect' properly. He only aims at finan- 
cial success and thus ultimately fails to create the transcultural space that is expected of him. He exercises his authority over everything and applies all sorts of brutality, extreme forms of violence, to establish his unquestionable authority. Marlow is shocked at the cruel treatments imposed by Kurtz on the natives. He disapproves of Kurtz's behavior and appearance:

I had a vision of him on the stretcher, opening his mouth voraciously, as if to devour all the earth with all its mankind. He lived then before me; he lived as much as he had ever lived - a shadow insatiable of splendid appearances, of frightful realities; a shadow darker than the shadow of the night, and draped nobly in the folds of a gorgeous eloquence. (95)

It is Kurtz's greed and brutality that lead to his death. Marlow states about Kurtz: "I had to deal with a being to which I could not appeal in the name of anything high or low. I had, even like the niggers, to invoke himself - his own exalted and incredible degradation. There was nothing either above or below him, and I knew it. He had kicked himself loose of the earth. Confound the man!" (85). Kurtz forgets all about the norms of a civilized life. His fanatical egoism fails to connect passion with reality as it happens in case of others. Kurtz's final utterance, "The horror! The horror!" reminds us of the horror lurking within us, the horror emanating from our inability to connect instinct with ideology. If we can cross the borders we can create a space that can be shared by all and the horrors will automatically get dissolved.

Thus both Conrad and Forster propose connections where all lines of demarcation become dissolved and the human entity is upheld. Forster's philosophy- "connect without bitterness until all men are brothers" (Howards End 266; ch. 33) —rises to the level of a common guiding principle in both writers. In this respect, both authors cross temporal and spatial boundaries, thus becoming universal.

\section{WORKS CITED}

Achebe, Ch., "An Image of Africa: Racism in Conrad's Heart of Darkness,” Massachusetts Review 1977, no. 18 , pp. 782-794.

Blackburn, W. (ed.), Joseph Conrad: Letters to William Blackwood and David S. Meldrum, Durham: Duke UP, 1958.

Childs, P. (ed.), E. M. Forster's A Passage to India, Routledge Guides to Literature, London \& New York: Routledge, 2002. First Indian Reprint, 2004.

Clifford, H., "The Art of Joseph Conrad," The Spectator, 29 Nov 1902. Qtd. in J. Raskin, "Imperialism: Conrad's Heart of Darkness," Journal of Contemporary History 1967, vol. 2, no. 2:

Literature and Society: 113-131, http://www.jstor.org/stable/259954 (access: 2 July 2016).

Connolly, C., Enemies of Promise, Harmondsworth: Penguin, 1961.

Conrad, J., Heart of Darkness [1899], ed. B. Bose, New Delhi: Oxford UP, 2001. -, Youth: A Narrative and Two Other Stories [1902], London: W. Blackwood and Sons, https://archive.org/details/youthnarrativetw00conrrich (access: 3 July 2016).

----------, Notes on Life and Letters [1920], eBook ed. USA: Start Publishing LLC, 2012, https://books.google.co.in/books?isbn=1633550885 (access: 3 July 2016).

Eagleton, T., Criticism and Ideology: A Study in Marxist Literary Theory, London: Verso, 1976. 
Forster, E. M., A Passage to India [1924], Penguin Classics, ed. O. Stallybrass, London: Penguin, 2005.

Howards End [1910], London: Penguin Books, 1989.

'Hill of Devi' and Other Indian Writings, ed. E. Heine, New York: Abinger, 1983.

Furbank, P. N., E. M. Forster: A Life, vol. 2 [1978], London: Cardinal: Sphere, 1998.

Garnett, E., "Mr Conrad's New Book," The Academy and Literature, 6 December 1902. Qtd. in J. Raskin, "Imperialism: Conrad's Heart of Darkness," Journal of Contemporary History 1967, vol. 2, no. 2: Literature and Society: 113-131, http://www.jstor.org/stable/259954 (access: 2 July 2016).

Haugh, R. F., "Heart of Darkness: Problem for Critics" [in:] J. Conrad, Heart of Darkness: An Authoritative Text, Background and Sources Criticism, Norton Critical Edition, $3^{\text {rd }}$ ed., New York: W. W. Norton \& Company, 1987.

Hoerder, D., "Transculturalism(s): From Nation-State to Human Agency in Social Spaces and Cultural Regions" [in:] Global Realignments and the Canadian Nation in the Third Millennium, ed. K. Ikas, Wiesbaden: Harrassowitz, 2010.

Kimbrough, R. (ed.), Heart of Darkness: An Authoritative Text, Background and Sources Criticism, Norton Critical Edition, $3^{\text {rd }}$ ed., New York: W. W. Norton \& Company, 1988.

Phillips, C., "Out of Africa," 22 February 2003, http://www.carylphillips.com/out-of-africa.html (access: 2 July 2016).

Raskin, J., "Imperialism: Conrad's Heart of Darkness," Journal of Contemporary History 1967, vol. 2, no. 2: Literature and Society: 113-131, http://www.jstor.org/stable/259954 (access: 2 July 2016).

Said, E., Culture and Imperialism, New York: Vintage Books, 1994.

Singh, F. B., "The Colonialistic Bias of Heart of Darkness" [in:] J. Conrad, Heart of Darkness: An Authoritative Text, Background and Sources Criticism, Norton Critical Edition, $3^{\text {rd }}$ ed., New York: W. W. Norton \& Company, 1987, pp. 268-77.

Watt, I., Essays on Conrad, Cambridge: Cambridge University Press, 2004.

Zins, H., Joseph Conrad and Africa, Nairobi: Kenya Literature Bureau, 1982. 